Magdalena Sasin

Uniwersytet Łódzki

\title{
Samokształcenie w działalności pedagoga sztuki w świetle opinii studentów - przyszłych nauczycieli
}

Samokształcenie to aktywność, która współcześnie nabiera coraz większej wagi. Dynamiczne zmiany we wszystkich niemal dziedzinach życia wymagają elastyczności, gotowości do weryfikowania swojej wiedzy i do nabywania nowych umiejętności. Te działania mają znaczenie nie tylko w pracy zawodowej, ale także w życiu prywatnym, gdyż bez nich nie jest możliwe pełne rozumienie otaczającego świata ani aktywne uczestnictwo w kulturze.

Bez samokształcenia nie można sobie wyobrazić wrażliwego, refleksyjnego odbiorcy sztuki. Nie sposób też wyobrazić sobie nauczyciela, który uczniom tę sztukę i świat przybliża. Nauczyciel musi nadążać za zmianami w otaczającym świecie, by zmiany te uczniom przedstawiać oraz by znajdować płaszczyznę porozumienia z młodzieżą, która obraca się głównie w świecie kultury popularnej. Popkultura jest zaś wyjątkowo kapryśna, a mody i tendencje zmieniają się niemal $\mathrm{z}$ sezonu na sezon.

Przekonanie o znaczeniu samokształcenia wdziałalności pedagoga, zwłaszcza pedagoga sztuki, podyktowało temat badań, które zostały przeprowadzone wśród studentów Wydziału Nauk o Wychowaniu Uniwersytetu Łódzkiego, specjalności edukacja przez sztukę.

Samokształcenie, choć tak istotne, jest zjawiskiem w pedagogice niedocenianym. Stosunkowo niewiele powstało literatury i badań naukowych na ten temat. Wśród autorów nie ma także zgodności co do zakresu terminu „samokształcenie” i terminów pokrewnych.

Pojęcie samokształcenia stosowane jest w literaturze pedagogicznej, psychologicznej i socjologicznej w znaczeniu wąskim lub szerokim. W ujęciu wąskim jego znaczenie ogranicza się do samodzielnego nabywania wiedzy i zdobywania sprawności pozwalających na korzystanie z niej; taki zakres znaczeniowy można znaleźć m.in. u Stanisława Karasia, który na podstawie analizy literatury przedmiotu dochodzi do wniosku, że samokształcenie to „samodzielne, świadome, celowe i poddane własnej kontroli 
zdobywanie i modernizowanie wiedzy ogólnej bądź kwalifikacji zawodo-

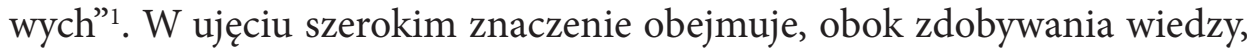
także doskonalenie umiejętności oraz formowanie osobowości i charakte$\mathrm{ru}$, a nawet kształtowanie autonomii jednostki; terminem „samokształcenie" w tym rozumieniu posługują się m.in. Jerzy Semków, Jadwiga Baranowska, Florian Znaniecki, Witold Okiński i Czesław Kupisiewicz. Według Aleksandra Kamińskiego, jest to „samodzielnie, świadomie podjęta praca nad własną osobą, w szczególności nad rozwojem własnej wiedzy, własnych umiejętności, poglądów i przekonań, własnego charakteru, praktykowane indywidualnie lub zespołowo, albo w autonomicznym koleżeńskim gronie lub całkowicie samodzielnie"2.

Pojęcia bliskoznaczne do terminu „samokształcenie” to: „samowychowanie”, „samodoskonalenie”, „autoedukacja”, „samouctwo”, a także „autokreacja” i „samourabianie" (termin stosowany przez Floriana Znanieckiego) ${ }^{3}$. Samokształcenie związane jest z pojęciem samouctwa: niekiedy utożsamia się te terminy, niektórzy pedagodzy zaś, tacy jako Antoni Dobrowolski, wiążą samouctwo ze zdobywaniem wykształcenia zawodowego, podczas gdy samokształcenie odnoszą do wykształcenia ogólnego. Według Franciszka Urbańczyka, samouctwo oznacza przyswojenie wiedzy na poziomie elementarnym i stanowi niższy poziom samokształcenia. Inni autorzy (np. Stefan Baley) uznają, że samouctwo odnosi się do dzieci, podczas gdy samokształcenie dotyczy młodzieży i dorosłych. Irena Jundziłł postrzega zaś samokształcenie jako składową procesu samowychowania.

Walentyna Wróblewska posługuje się pojęciem „autoedukacja”, uzasadniając, że jest ono „najtrafniejszym określeniem ustawicznego procesu wielostronnego rozwoju osobowości człowieka”4 i łączy procesy samokształcenia i samowychowania, dotychczas sztucznie rozdzielane.

W przedstawionych badaniach zdecydowano się na zastosowanie terminu „samokształcenie” jako określenia najczęściej używanego zarówno w literaturze naukowej, jak i w języku potocznym. Badanie zostało przeprowadzone w listopadzie 2012 roku w grupie 12 osób, przyszłych nauczycieli: studentów I roku studiów II stopnia (magisterskich) specjalności edukacja przez sztukę na Wydziale Nauk o Wychowaniu Uniwersytetu Łódzkiego.

\footnotetext{
${ }^{1}$ S. Karaś, Sztuka samokształcenia, Warszawa 1994, s. 10.

${ }^{2}$ A. Kamiński, Funkcje pedagogiki społecznej, Warszawa 1971, s. 19, za: W. Wróblewska, Autoedukacja studentów w uniwersytecie - ujęcie z perspektywy podmiotu, Białystok 2008, s. 23.

${ }^{3}$ D. Jankowski, Autoedukacja wyzwaniem wspótczesności, Toruń 2000.

${ }^{4}$ W. Wróblewska, Autoedukacja studentów..., s. 47.
} 
Większość moich rozmówców to osoby kontynuujące studia na tym samym kierunku, a nawet specjalności. Niektórzy już teraz pracują w niepełnym wymiarze godzin w wybranym zawodzie.

Uznano, że dla wstępnego poznania opinii studentów na postawiony temat najwłaściwsza będzie metoda dialogowa, przeprowadzona w technice rozmowy grupowej. Jak podkreśla Mieczysław Łobocki, „podejmowanie rozmowy grupowej jest wskazane zwłaszcza w przypadku omawiania tematów dotyczących spraw, które niemal w jednakowym stopniu znane są wszystkim jej uczestnikom i nie są związane z ich sferą intymną" ${ }^{5}$. Rozmowa grupowa, bardziej niż indywidualna, ma szansę ośmielić niektóre osoby do czynnego udziału, bo obecność innych odbierają jako wsparcie w swobodnym i szczerym wypowiadaniu się. Rozmowa grupowa zyskuje na wartości poznawczej dzięki temu, że wypowiedzi niezgodne z poglądami innych uczestników są na ogół przez nich korygowane, uzupełniane i pogłębiane. Interakcje między członkami grupy sprzyjają formułowaniu opinii i wymianie myśli. Z dwóch możliwości - rozmowy polegającej na słuchaniu biernym i czynnym - wybrano tę drugą.

Badanie było anonimowe, udział w nim całkowicie dobrowolny. Autorka jest świadoma, że taka metoda zastosowana samodzielnie nie jest wyczerpującą i wystarczającą metodą badawczą; powinna być łączona $\mathrm{z}$ innymi metodami: eksperymentalnymi, testowymi, socjometrycznymi itd. Dlatego wyniki prezentowanego badania należy traktować jedynie jako zarysowanie problemów badawczych i hipotez roboczych.

Grupa wypowiadających się osób ma znaczenie dla interpretacji uzyskanych wyników. Studenci I roku studiów magisterskich dysponują nie tylko pewną pulą wiedzy z zakresu wybranej dziedziny studiów, ale także wiedzy związanej z funkcjonowaniem rynku pracy. Można też przyjąć, że posiadają oni znaczący stopień samowiedzy dotyczącej zaangażowania w samokształcenie, siły swojej motywacji oraz konsekwencji w działaniu, co pozwala im z dużym prawdopodobieństwem wypowiadać się nie tylko na temat swoich działań teraźniejszych, ale także przyszłych.

Rozmowa ze studentami na temat samokształcenia zachęciła ich do refleksji na ten ważny temat i sprowokowała do sformułowania niektórych sądów i opinii, a także wątpliwości, których być może nie byli wcześniej świadomi.

\footnotetext{
${ }^{5}$ M. Łobocki, Metody i techniki badań pedagogicznych, Kraków 2007, s. 281.
} 
Podczas badania celowo nie dookreślono pojęcia "samokształcenie”, chcąc dowiedzieć się, jaki zakres znaczeniowy przypisują mu osoby badane. W zdecydowanej większości przypadków wypowiedzi ograniczały się do tematyki wykształcenia, wiedzy i umiejętności, pomijały zaś zagadnienia kształtowania osobowości i charakteru. Tylko jedna studentka zwróciła uwagę, że wiedza poszerza horyzonty i w ten sposób może wpływać na zmianę postaw:

Dzięki temu, że poszerzamy nasze horyzonty, to też uczymy się takiej tolerancji wobec wszystkiego, co jest inne, nam nieznane. Zazwyczaj człowiek obawia się tego, boi się tego, czego nie zna. Uczymy się tolerować tę odmienność i uczymy się o tym, że jest mnóstwo rzeczy, które sa inne, po prostu, i których nie znamy, i które nie muszą nam się koniecznie podobać.

Samokształcenie to proces nieograniczony ramami czasowymi: nie da się określić punktu, w którym mógłby się on zakończyć. Postawa samokształceniowa obowiązuje przez całe życie. Potrzebę całożyciowego podejścia do samokształcenia bierze pod uwagę Unia Europejska, której program dotyczący edukacji i doskonalenia zawodowego na lata 2007-2013 został nazwany „Lifelong Learning Programme”, czyli „Uczenie się przez całe życie”. Cele tego programu stanowią, że ma on wspierać realizację europejskiego obszaru uczenia się przez całe życie, podnosić jakość, atrakcyjność i dostępność ofert w tym zakresie oraz przyczyniać się do udziału w uczeniu się przez całe życie osób z różnych środowisk i grup społecznych ${ }^{6}$.

Z konieczności traktowania samokształcenia jako postawy całożyciowej zdają sobie sprawę badani studenci. Wskazują na dynamiczne przemiany współczesnego świata, których skutkiem są m.in. zmiany w zachowaniu i zainteresowaniach młodzieży, z którą pracują nauczyciele.

Ja nie wiem, czy w życiu jakiegokolwiek człowieka byt kiedyśs taki punkt, [...] że o, już jestem maksymalnie wykształcony, już dalej mi nie potrzeba, nie będę się dalej kształcił. Myślę, że każdy chyba ma jakieś takie poczucie, że ten świat się zmienia, potrzeby się zmieniają, sposób nauczania się zmienia, młodzież się zmienia, która nauczamy, więc chyba to jest naturalny proces, który trwa do końca.

Jest to proces istotny nie tylko dla pedagoga ze specjalnościa edukacji przez sztukę, tylko w ogóle dla każdego pedagoga. To jest związane $z$ [...] praca z ludźmi, a my pracujemy z ludźmi szczególnymi, mamy pracować z dziećmi czy z młodzieża.

${ }^{6}$ Program „Uczenie się przez całe życie”. Zaproszenie do składania wniosków 2011-2013. Priorytety strategiczne 2012, http://www.llp.org.pl/doc/LLP_2012.zip (dostęp: 3.02.2013). 
Nie tylko jednak pedagodzy, zdaniem moich rozmówców, są zobligowani do ciągłego doskonalenia się. Nieustanny rozwój dotyczy każdego świadomego, otwartego na świat człowieka, niezależnie od uprawianego zawodu.

Jeżeli ktoś żyje świadomie, to na pewno będzie się samokształcił, chociażby dlatego, żeby robić to dla siebie, żeby nie stać się skostniałym i zupetnie nieużytecznym do życia. Człowiek musi nadażyć za światem, za samym soba, bo każdy dzień daje nam nowe bodźce i $[\ldots]$ musimy mieć wiedzę taką, żeby tworzyć jakiekolwiek opinie na dany temat.

Studenci zwracają uwagę, że dążenie do samokształcenia nie tylko wynika z warunków zewnętrznych, ale także świadczy o określonym typie charakteru i osobowości. Do zaangażowania w samokształcenie bardziej skłonne są osoby o sprecyzowanych planach zawodowych na przyszłość i silnej motywacji.

W moim przypadku to jest tak, że sama chcę się dokształcać i mam tę możliwość. Poprzez różne znajomości i to, jaki charakter ja mam i to, że zdecydowanie chce pracować w zawodzie.

Dużo zależy od indywidualnego charakteru każdej osoby, bo każdy jest zupetnie inny, od motywacji, od naszych planów, no i od tego, jak życie to zweryfikuje.

Studia zmieniły u niektórych osób nastawienie do zawodu nauczyciela: z początkowo niechętnego na ostrożnie optymistyczne.

Przychodząc na te studia myślałam, że tylko będę się samorealizować, a [zajęcia pedagogiczne] to tylko taki dodatek, żeby zobaczyć, jak to będzie. Ale po praktykach, które mieliśmy w szkole, stwierdziłam, że jednak warto by to wykorzystać do pracy z ludźmi [...] i fajnie by było, żeby coś dać z siebie innym.

Samoakceptacja w zawodzie nauczyciela jest bardzo istotna, gdyż, jak wskazują badania ${ }^{7}$, podnosi motywację do pracy i dokonywania w niej zmian, a więc stanowi jeden z czynników sprzyjających samokształceniu. W świetle tych rezultatów można stwierdzić, że wybieranie zawodu nauczyciela z konieczności, bez przekonania prowadzi do przyjmowania postawy biernej. Należałoby zatem stwarzać studentom możliwości identyfikacji z potencjalnym przyszłym zawodem, np. poprzez działania nieobowiązkowe w szkołach, domach kultury itp.

\footnotetext{
${ }^{7}$ S. Koczoń-Zurek, Między podtrzymywaniem a zahamowaniem aktywności zawodowej nauczyciela, „Chowanna”, Katowice 2006, t. I (26), s. 143-156.
} 
Podejmowanie samokształcenia powinno być samodzielną decyzją danej osoby, ale proces ten nie przebiega w izolacji. Pozytywny wpływ mogą wywierać inne osoby, które stanowią wzór osobowy, dostarczają inspiracji, a nawet pomagają w konkretny sposób, choćby pożyczając potrzebne materiały książkowe.

Mnie akurat bardzo dużo daje harcerstwo, większość ciekawych instruktorów tam pracuje, więc mam duże pole do popisu.

Mam do kogo się zwrócić, bowiem w mojej rodzinie sa nauczyciele i mam to ułatwienie, że zawsze mogę liczyć na to, że ktoś mi coś poradzi i podeśle mi taka a nie inną książkę. Często z tego korzystam, bo jest to mój pierwszy kontakt $z$ dziećmi, moja pierwsza taka praca.

Wiele uwagi studenci poświęcają przemianom kulturowym i technologicznym zachodzącym we współczesnym świecie. Dostrzegają zarówno wady, jak i zalety cywilizacji, w jakiej przyszło im żyć, nowinek technicznych, które w krótkim czasie stają się niemal obowiązkowym elementem codzienności, bogactwa wszystkiego wokół: informacji, ofert, towarów. Właśnie pośpiech i nadmiar to najczęściej wymieniane przez moich rozmówców negatywne strony współczesnej cywilizacji, które utrudniają samokształcenie, gdyż nie sprzyjają refleksji ani uporządkowanemu działaniu.

Teraz właściwie jest ciężej, bo jak gdyby całe życie przyspieszyło. Ja właściwie nie mam takiego czasu, kiedy mogłabym mieć chwilę na dłuższa autorefleksje, żeby uporzadkować doznania chociażby.

Nie możemy sobie na spokojnie usiąśc, przemyśleć, porównać, tylko chwytamy wszystko, żeby mieć jak najwięcej. I krztusimy się czasami tym wszystkim, jesteśmy przez to mniej efektywni.

Przez to, że jest tak du̇zy wybór tych kursów, szkoleń, trudno jest nam wybrać coś, co jest dopasowane do tego, czego my sobie życzymy.

Niewątpliwym ułatwieniem w samokształceniu jest Internet, który umożliwia szybkie przesyłanie i wyszukiwanie informacji, a nawet staje się pośrednikiem przekazującym usługi edukacyjne (e-learning). Odgrywa jednak pozytywną rolę tylko wtedy, gdy właściwie się z niego korzysta, nie powinien bowiem zastępować samodzielnej pracy.

Dużym ułatwieniem $w$ dzisiejszych czasach jest Internet, bo czasami można tam naprawdę wiele znaleźć dobrych pomysłów: jak poprowadzić zajęcia, jak napisać plan odpowiedni do danej grupy wiekowej. Myślę, że mamy troszkę łatwiej, 
jeżeli chodzi o samokształcenie [niż poprzednie pokolenia], że jednak ta wiedza jest bardziej dostępna.

Ale nie jest tak, że wklepię [w wyszukiwarkę internetową] jakieś byle co. Staram się poszukiwać jakichś inspiracji, później idę do biblioteki. Internet [...] jest takim poczatkiem, który inspiruje do dalszego działania. I myśle, że to jest dobre, że możemy będąc $w$ domu wejść sobie na jakąś stronę, pomyśleć o czymś, na czym chcielibyśmy się skupić, i później samemu dążý do tego stopniowo i na tyle, na ile pozwala nam czas.

Samokształcenie odgrywa istotną rolę w obcowaniu ze sztuką, gdyż wymaga ona indywidualnego kontaktu odbiorcy z dziełem. Przeżycia estetyczne nie podlegają ujednoliceniu i każdy odbiorca ma prawo do własnej interpretacji. Z drugiej strony, istnieją pewne ogólne kryteria oceny i odbioru dzieł sztuki i każda próba zrozumienia ich przybliża nas do zrozumienia ducha epoki, w której dzieło powstało. Sztuka pełni też funkcję poznawczą; dzięki niej można zbliżyć się do zrozumienia przeżyć i uczuć innych ludzi, które nie poddają się werbalizacji.

Sztuka jest odzwierciedleniem wszystkich niepokojów człowieka, jest też forma komunikowania się ze światem [...] Uważam, że sztuka jest idealna do tego, żeby obrazować wszystko to, co mamy w środku i jeżeli jesteśmy świadomi tego, poszczególnych tendencji panujących w epokach, czy obserwujemy to, co się obecnie dzieje, to jesteśmy też $w$ stanie zrozumieć drugiego człowieka.

To jest trochę tak, jak z małym dzieckiem: patrzy na jakiś przedmiot, i mu się podoba ten przedmiot, ale nie wie, do czego on służy. Tak samo jest ze sztuka: możemy na coś patrzeć, ale nie wiemy, jak to odbierać. [...] Ktoś mówi na przykład, że mu się nie podoba ta czy ta piosenka, ale nie wie, jakie były założenia epoki. [...] Myślę, że to jest podstawa, żeby móc się wypowiadać i żeby móc odbierać coś w prawidłowy sposób.

Samokształcenie w pracy nauczyciela ma znaczenie nie tylko jako sposób poszerzania wiedzy, ale także ze względu na tworzenie wzoru osobowego dla wychowanków. Tylko nauczyciel zaangażowany w zdobywanie wiedzy i autentycznie zafascynowany otaczającym światem jest w stanie takie zainteresowanie obudzić u swego ucznia. Znaczenie wzoru osobowego nauczyciela studenci oceniają na podstawie własnych doświadczeń z dzieciństwa. Pamięć o zaangażowanych w swoją pracę, pełnych entuzjazmu pedagogach pozostaje na wiele lat, a zainteresowanie przez nich obudzone ma szansę przetrwać nawet do wieku dorosłego. 
Przykład idzie z góry $i[. .$.$] dzieci naturalnie szukaja jakiegoś autorytetu do$ naśladowania i najwygodniej im znaleźć w najbliższym otoczeniu. Wiadomo, że w pierwszej linii to będa rodzice, zależy też od etapu rozwoju, potem nauczyciele, starszy brat, starsza siostra.

Ja taki przykład bardzo $z$ dzieciństwa bym mogła tu powiedzieć, nawet z przedszkola. Ponieważ miałam pania od plastyki i już właśnie od tego momentu dostałam taka inspirację, od dziecka, że będę malować, że będę tworzyć. [...] I też widziałam, w jaki sposób ona opowiadała o swoich doświadczeniach, na przykład o zwiedzaniu różnych rzeczy, porównywała, różne przykłady podawała, też przynosiła różne materiały, więc to było takie bardzo, z każdej strony oddziaływanie na uczniów.

Pasja i zaangażowanie to pożądane cechy pedagoga niezależnie od obowiązującego w danym okresie systemu edukacji. Obecnie realizowany model kształcenia, w którym kładzie się nacisk na rozwijanie indywidualności ucznia i kształtowanie jego zainteresowań, w sposób szczególny wymaga od nauczyciela kreatywności i samokształcenia. Studenci dostrzegają te przemiany. W odniesieniu do nauczycieli muzyki podkreślają, że jeszcze niedawno byli oni z reguły gruntowniej wykształceni i posiadali wyższe umiejętności, natomiast ich praca mogła być bardziej standardowa i powtarzalna. Obecnie zaś dysponują skromniejszymi umiejętnościami, oczekiwania uczniów i rodziców są zaś znacznie wyższe. Wysiłek, który kiedyś podejmowali sami uczniowie, np. w zakresie poznawania różnych utworów muzyki rozrywkowej, został w znacznym stopniu przerzucony na barki nauczyciela. Zarówno uczniowie, jak i rodzice podchodzą do jego pracy bardzo krytycznie i są skłonni do wydawania surowych ocen.

Powiem na przykładzie muzyki, bo to jest mi najbardziej bliskie. Wydaje mi się, że kiedyś nauczyciel od muzyki, czy to w szkole czy w domu kultury, był dobrze wykształcony muzycznie, w sumie chyba lepiej niż teraz. Natomiast grał tylko to, co było w programie. Jeśli młodzież chciała czegoś więcej, musiała dojść do tego indywidualnie. Teraz jest tak, że wymaga się tego od nauczyciela. Pracując $z$ młodzieżą $w$ domu kultury [zauważam, że] obowiązkowa jest moja forma jakiegoś samokształcenia dodatkowego, ponieważ młodzież wymaga teraz więcej.

Jeżeli chcielibyśmy być dobrze postrzegani przez naszych uczniów i dobrze się czuć $w$ tej pracy, musimy się właśnie dokształcać, poszukiwać jakichś nowych technik, jeżeli chodzi o zajęcia plastyczne, czy jakichś sposobów przekazywania wiedzy muzycznej, [...] jakichś takich niekonwencjonalnych metod działania.

Studenci podają w wątpliwość zasadność łączenia w pracy nauczycieli wątków z różnych dziedzin sztuki na zasadzie równorzędności. Uważają, że skuteczniej może uczyć ten, kto specjalizuje się w wybranym obszarze. Ich 
opinie współbrzmią w ten sposób z głosami krytycznymi wielu naukowców, pedagogów i rodziców, które doprowadziły do likwidacji przedmiotu sztuka i powrotu do obowiązujących wcześniej muzyki i plastyki.

Takie zawsze u mnie panowało przekonanie, że jak coś jest do wszystkiego, to jest do niczego. Jest taka moda na tego pedagoga humanistę, który powinien potrafić wszystko, żeby się dostosować do dynamicznej sytuacji, no ale nie jestem w żaden sposób przekonana, czy jest to coś dobrego. Nie wiem, czy taka osoba, która później podejmuje tę pracę zawodową, zajmie się czymś konkretnym, czy ona będzie dobra w tym.

Konieczność sprostania wzrastającym wymaganiom rynku pracy prowadzi do próby oceny, w jakim stopniu studia pedagogiczne przygotowują przyszłych nauczycieli do odgrywania tej wymagającej roli. Studenci, z którymi przeprowadzono badania, formułują szereg zastrzeżeń co do planu swoich studiów ${ }^{8}$. Uważają, że realizowanych jest zbyt mało przedmiotów specjalnościowych i w siatce godzin pojawiają się one zbyt późno. Na pierwszym roku studiów zarówno licencjackich, jak i magisterskich nie przewidziano przedmiotów specjalnościowych, co powoduje, że student czuje się „oderwany” od przedmiotu swoich zainteresowań artystycznych.

Te osoby, które kontynuuja te studia [magisterskie], niech sobie odpowiedza $w$ duchu, czy czują się na tyle kompetentne, żeby móc prowadzić zajęcia z jakiejkolwiek dziedziny. Jeśli ja mam odpowiedzieć, to mówię nie, i żadne z tych zajęć, które tutaj byty proponowane, nie sa $w$ stanie $w$ stu procentach mnie przygotować, i stąd jest potrzeba dokształcania, kursów.

Program studiów nakreśla obraz tego, że potrzebne jest nam samokształcenie. Jesteśmy na edukacji przez sztukę. Przez pierwszy rok nie mieliśmy żadnych przedmiotów artystycznych, wszystko było ogólnopedagogiczne. Na pierwszym roku studiów drugiego stopnia jest tak samo. I to jest takie troszeczkę hamujace. I to jakby nie ma zwiazku z tym, że mamy zainteresowania muzyczne, plastyczne, teatralne, i nie odzwierciedla tego, co byśmy chcieli robić.

Ludzie, którzy tu przychodza, widzac program studiów i patrzac na nasz plan zajęć, od razu zaczynaja szukać działalności artystycznej gdzie indziej, żeby się gdzieś zahaczyć, na przykład w domu kultury. Zajmuja sobie tam wolny czas i nie myślq o założeniu [czegoś] tutaj [na uniwersytecie].

\footnotetext{
${ }^{8}$ Program studiów przygotowujących do zawodu nauczyciela przedmiotów artystycznych może różnić się dość znacznie w zależności od uczelni. Por. np.: B. Kamińska, Problemy związane z przygotowaniem nauczycieli przedmiotów artystycznych do realizacji procesów edukacji muzycznej dzieci i młodzieży, [w:] M. Zalewska-Pawlak, A. Pikała (red.), Szkoła XXI wieku - szkoła edukacji estetycznej. Projekt nadziei, Łódź 2011, s. 97-112.
} 
Krytyka programu studiów ma związek z wysokimi oczekiwaniami studentów; tymczasem w rzeczywistości żadne studia nie są w stanie przygotować przyszłego nauczyciela „w stu procentach”. Wysokie oczekiwania wobec programu studiów są z kolei pochodną oczekiwań, jakie uczniowie i rodzice mają wobec nauczycieli: są one niejednokrotnie wygórowane, wręcz niemożliwe do spełnienia dla młodego pedagoga. Ten problem analizuje Beata Kamińska ${ }^{9}$ na przykładzie nauczyciela muzyki: powinien grać na instrumentach, śpiewać, akompaniować, posiąść podstawy aranżacji, umieć słuchać muzyki i uczyć tego innych, a nawet dyrygować - to na pewno nie wszystko, a tymczasem „na pewno powierzchownie przyszli nauczyciele są przygotowani pod względem przedmiotów artystycznych" ${ }^{\prime 0}$.

Choć nie jest możliwe, by studia w pełni przygotowały nauczycieli do zawodu, należy dążyć do tego, by wszystkie najważniejsze wiadomości i umiejętności specjalizacyjne znalazły odzwierciedlenie w ich programie. Podjęcie samokształcenia powinno bowiem wynikać z pojawienia się ciekawości poznawczej, a do tego potrzebne jest zdobycie pewnego poziomu wykształcenia, który daje świadomość własnej niewiedzy i rodzi chęć jej uzupełnienia. Zwraca na to uwagę D. E. Berlyne: „Ciekawość poznawcza nie jest największa w przypadku największej ignorancji, lecz wzrasta aż do pewnego punktu w miarę wzrastania wiedzy"11.

Samokształcenie przyszłych nauczycieli może się odbywać w dwóch podstawowych zakresach: umiejętności pedagogicznych, potrzebnych nauczycielowi niezależnie od jego specjalności, i umiejętności specjalistycznych, właściwych dla danej dziedziny wiedzy. Studenci kładą nacisk na drugi z wymienionych obszarów, całkowicie pomijając pierwszy.

Mamy za mało praktyki, bo uczymy się masy teorii, a nie możemy się wdro$\dot{z} y c ́$ w cały system nauczania i konfrontacji z jednostkami, którym mamy przekazać wiedzę. Przez to nie zdajemy sobie sami sprawy z naszych braków i nie wiemy, jak się kształcić, żeby stać się bardziej efektywnym i żeby łatwiej się nam pracowało i przekazywało to, co już wiemy, oraz rozwijało te sfery, które nadal sa spychane na dalszy plan.

Studenci poruszają także inną kwestię, związaną z poziomem zajęć na specjalności edukacja przez sztukę: problem selekcji kandydatów na studia. Zgodnie z przyjętymi założeniami, rekrutacja kandydatów odbywa

\footnotetext{
${ }^{9}$ B. Kamińska, Problemy związane z przygotowaniem nauczycieli...

${ }^{10}$ Ibidem, s. 100.

${ }^{11}$ D. E. Berlyne, Struktura i kierunek myślenia, Warszawa 1969, s. 324, cyt. za: A. Gurycka, Rozwój i ksztattowanie zainteresowań, Warszawa 1989, s. 151.
} 
się na podstawie wyników egzaminów maturalnych, jak obecnie na większości kierunków studiów, zwłaszcza humanistycznych. W związku z tym większość studentów nie posiada żadnego przygotowania artystycznego, a nawet nie dysponuje wiedzą przewidzianą w programie szkoły ogólnokształcącej. Co więcej, niektórzy studenci z trudem i niechętnie przełamują opory przed zabieraniem głosu na zajęciach, wystąpieniami publicznymi, prowadzeniem zajęć, jakby nie zdając sobie sprawy, że w wybranym przez nich zawodzie będzie to codzienność. Zaniża to poziom zajęć i utrudnia kształcenie osobom o wysokiej motywacji.

Mamy potem uczyć innych, więc powinniśmy być kompetentni w obrębie tych przedmiotów, do których mamy uprawnienia. [Powinno się] mieć pojęcie o niektórych dziedzinach sztuki, o podstawach. Nie rozumiem, jak ktoś przychodzi na edukacje przez sztukę i nie potrafi powiedzieć, co to jest pótnuta, a co to jest ósemka. Albo mówi, że on na studiach pedagogicznych zajęć nie będzie prowadził, bo się wstydzi wystapień publicznych. To już mnie przeraża. [...] niestety jest grono osób, które [traktują te studia jak] taki dodatek do życia, a ich to nie interesuje. To też sprawia, że te studia sa postrzegane z zewnatrz jako łatwe albo mało prestiżowe. Bo osoby, które tu studiują, nie mówię o wszystkich oczywiście, nie mają zielonego pojęcia, co tutaj robia.

Studenci zgodni są co do tego, że aby być dobrymi pedagogami, muszą się dokształcać samodzielnie. Plany z tym związane różnią się jednak wśród nich znacząco. Niektóre osoby przez cały okres studiów są aktywne w wybranej przez siebie dziedzinie: biorą udział w zajęciach i kursach w domach kultury, grają w zespołach muzycznych, są wolontariuszami itp. Inni bardziej intensywne samokształcenie odkładają na czas po studiach, argumentując, że brak im czasu i pieniędzy. Dotyczy to zwłaszcza osób przyjezdnych, które muszą pokryć koszty swego utrzymania, oraz osób, które znaczną część czasu przeznaczają na dojazdy. Coraz większa liczba studentów pracuje zarobkowo, także w znacznym wymiarze godzin, co faktycznie utrudnia znalezienie czasu na zajęcia dodatkowe.

Myślę, że sa wśród nas osoby, które mają na myśli od samego początku tych studiów to, czym chciałyby się zajmować. Ja jestem ukierunkowana na muzykę i od początku studiów jestem zaangażowana $w$ tego rodzaju działalność: zespół czy tworzenie jakichś projektów, sama też piszę, komponuję. To jest dla mnie priorytet. Dlatego też caly czas się tym zajmuję i temu poświęcam najwięcej czasu.

Nie mam jeszcze takiej możliwości, żeby podjać jakieś kroki w kierunku samokształcenia. Myślę, że gdy skończę studia, no to może coś później. Może jakaś furtka kolejna się otworzy, może będę miała więcej możliwości. Dużo czasu poświę- 
cam na to, żeby tutaj jakoś dać sobie radę na studiach, żeby pogodzić swoje życie prywatne, pracę. Chciałabym [pójśćc na jakiś kurs, chciałabym się wykształcić, ale nie mam na to pieniędzy, no to muszę iść do pracy. Jak idę do pracy, to nie mam na to czasu.

Wielu studentów nie dostrzega jednak możliwości bezpłatnego kształcenia się poza regularnymi zajęciami na uczelni, możliwości, które niewątpliwie istnieją. Stwarzają je między innymi działania w ramach wolontariatu, kursy finansowane z budżetu Unii Europejskiej ${ }^{12}$, zakładane i prowadzone samodzielnie przez studentów zespoły artystyczne różnych specjalności. Wiele osób zakłada, że po studiach ich możliwości zarówno czasowe, jak i finansowe będą większe. Życie uczy, że takie nadzieje często okazują się płonne.

Niepodejmowanie samokształcenia wiąże się także, u niektórych osób, z niesprecyzowaną wizją przyszłej pracy zawodowej.

Na przykład ja wybrałem arteterapię, że chcę to robić w przyszłości. Jeśli chce się do tego zawodu nauczyć, to muszę chodzić na jakieś kursy, muszę czytać ksiązki, muszę rozwijać to sam [...] To się zacznie i myślę, że to będzie dużo czasu: co najmniej rok [przeznaczony na dokształcanie po skończeniu studiów], tak optymistycznie zakładając. Jeśli na przykład skończę te studia i będę chciał być arteterapeutą, to [...] [będę pracował gdzie indziej w celach czysto zarobkowych] $i w$ wolnym czasie, który będę miał, jakoś się dokształcał.

Na razie nie [podejmuję samokształcenia], no bo jeszcze powiedzmy nie mam takiej wizji ustalonej, że o, idę tu i tu do pracy, i muszę się przygotować. To się zacznie i myślę, że to będzie dużo czasu [wymagało].

Myślę że, przynajmniej w naszym przypadku, po studiach będzie na to więcej czasu, przynajmniej każdy tak zakłada, oczywiście to się zweryfikuje.

W przeprowadzonych badaniach potwierdzono, że studenci z badanej grupy rozumieją i akceptują potrzebę samokształcenia, wynikającą zarówno $\mathrm{z}$ wybranego przez nich zawodu, jak i ze specyfiki czasów, w których żyją. Jednocześnie jednak ujawniło się wiele problemów z tym związanych; niektóre z nich mogą znaleźć choć częściowe rozwiązanie na studiach, podczas kontaktu z nauczycielami akademickimi.

Samokształcenie to proces wieloaspektowy, przez studentów jednak zbyt często utożsamiany $\mathrm{z}$ doskonaleniem intelektu. Ze studiów powinni oni wynieść przekonanie o wielostronnym, złożonym charakterze tego zja-

${ }^{12}$ Bezpłatne szkolenia są organizowane m.in. ze środków Europejskiego Funduszu Społecznego; http://www.inwestycjawkadry.info.pl/informacje_efs.html (dostęp: 5.02.2013). 
wiska, w którym rozwój wiedzy i umiejętności musi iść w parze z kształtowaniem przymiotów ducha.

Jednym z ważniejszych czynników motywujących do samokształcenia jest sprecyzowana wizja przyszłej pracy zawodowej. Wydaje się, że taka wizja powinna się ukształtować nie później niż w czasie studiów magisterskich. Należy zwracać na to uwagę studentów i zachęcać ich do refleksji, np. podczas obowiązkowych praktyk w instytucjach edukacyjnych.

W ułatwieniu studentom planowania i realizowania samokształcenia bardzo pomocne byłyby zajęcia z zakresu planowania kariery zawodowej i zarządzania sobą w czasie. W miarę możliwości dobrze byłoby rozważyć umieszczenie ich w programie studiów (opcjonalnie? W formie warsztatów?). Być może warto też przyjrzeć się programowi studiów i sposobom rekrutacji kandydatów, biorąc pod uwagę sugestie studentów. Młodym osobom przydatne byłoby też doradztwo w zakresie bezpłatnych lub nisko płatnych szkoleń i kursów z interesujących je dziedzin, co ułatwiłoby im podjęcie decyzji o samokształceniu.

Rozważania o samokształceniu pięknie podsumowuje myśl Maksyma Gorkiego: „prawdziwy nauczyciel winien być najpilniejszym uczniem”13. Gorki wskazuje, że nauczyciel i uczeń nie znajdują się po dwóch stronach barykady, lecz w istocie ich aktywność ma z sobą wiele wspólnego. Jest to istotne zwłaszcza obecnie, gdyż nauczyciel nie ma być już głównym źródłem wiedzy - dla swoich uczniów powinien stać się towarzyszem w uczeniu się i przewodnikiem po coraz bardziej skomplikowanym świecie. Ma stanowić przykład aktywnej postawy wobec życia, pokazywać, jak efektywnie pogłębiać swoją wiedzę i rozwijać umiejętności. Nauczyciel swoim działaniem powinien dawać przykład uczniowi i zarysowywać przed nim drogę, którą ten może podążać.

\section{Bibliografia}

Gurycka A., Rozwój i kształtowanie zainteresowań, Warszawa 1989. Jankowski D., Autoedukacja wyzwaniem wspótczesności, Toruń 2000.

${ }^{13}$ S. Koczoń-Zurek, recenzja książki Zbigniewa B. Gasia Doskonalący się nauczyciel, „Chowanna”, Wydawnictwo UŚ, Katowice 2006, tom 1 (26), s. 193. 
Kamińska B., Problemy związane z przygotowaniem nauczycieli przedmiotów artystycznych do realizacji procesów edukacji muzycznej dzieci i młodzieży, [w:] M. Zalewska-Pawlak, A. Pikała (red.), Szkoła XXI wieku - szkoła edukacji estetycznej. Projekt nadziei, Łódź 2011.

Karaś S., Sztuka samokształcenia, Warszawa 1994.

Koczoń-Zurek S., Między podtrzymywaniem a zahamowaniem aktywności zawodowej nauczyciela, „Chowanna” 2006, t. I (26).

Koczoń-Zurek S., recenzja książki Zbigniewa B. Gasia Doskonalący się nauczyciel, „Chowanna" 2006, t. I (26).

Łobocki M., Metody i techniki badań pedagogicznych, Kraków 2007.

Wróblewska W., Autoedukacja studentów w uniwersytecie - ujęcie z perspektywy podmiotu, Białystok 2008. 